\title{
Microbial Quality and Safety of Bread Sold in Cafeteria, Tea and Bread Shop of Jimma Town, Oromia Regional State, Southwest Ethiopia
}

Shiferaw Demissie* and Gadisa Natea

Department of Biology, Jimma University, Jimma, Ethiopia

\begin{abstract}
The globally popularity of the bread is could be due to it good aroma and flavor, and affordable for most of consumers and rich in carbohydrate. However, this delicious food is risk for health of people when contaminate with moulds and potential pathogenic bacteria. The aim of this study was to evaluate the microbiological quality and safety of bread sold in Jimma town. The study involved laboratory analysis for microbial quality and safety of bread. Standard methods were used for the enumeration of Enterobacteriaceae, Staphylococcus aureus, lactic acid bacteria, yeasts and moulds, antibiotic susceptibility patterns of the isolates. Data were analyzed using SPSS software version 16.00. A total of 90 bread samples (30 from each cafeteria, tea and bread shop) were collected. Result of the study indicated, the mean microbial counts (CFUg $\left.{ }^{-1}\right)$ were dominated by aerobic mesophilic bacteria (5.2 \pm 0.5 ), aerobic bacterial spore $(4.6 \pm 0.7)$, moulds $(4.0 \pm 0.6)$, S. aureus $(3.3 \pm 0.5)$, Yeast (3.0 \pm 0.6$)$, lactic acid bacteria $(2.5 \pm 0.4)$ and Enterobacteriaceae $(1.1 \pm 0.1)$, however, Coli form bacteria was not detected in any bread samples. Of the total of 546 isolates characterized, the most predominant were Bacillus spp. $(40.7 \%)$ followed by Staphylococcus spp. (25.1\%), Micrococcus spp. (10.6\%), Pseudomonas spp. (9.9\%), Acinetobacter spp. (7.7\%) and Aeromonas spp. (6\%). Totally, $68.9 \%$ of samples were positive for $S$. aureus but Salmonella spp. below detectable level in any bread sample of suppliers. $S$. aureus isolates were resistant to maximum seven antibiotics $(4.8 \%)$ and highly resistant to Methicillin, Oxacillin and Penicillin $\mathrm{G}$ $(100 \%)$. Bread contamination problems in present study could be due to poor personal hygiene, and improperly sanitized utensils. Generally, the microbial quality of bread sold in Jimma town was poor, particularly tea shop and cafeteria bread sellers needs regular inspection.
\end{abstract}

Keywords: Antibiotics resistance; Bread; Microbial quality; Safety; Pathogenic bacteria

\section{Introduction}

Bread is eaten all over the world by almost peoples of every culture. If we traveled to the other side of the planet we would probably find a culture very different from our own, yet with its own version of bread [1]. Therefore; bread is a food product that is universally accepted as a very convenient form of food that has desirability to all population rich and poor, rural and urban. Thus, none of any food types compute with bread in line with consumption in the world. In Nigeria, bread has become the second most widely consumed non-indigenous food product after rice [2]. Also in Ethiopia, next to Injera the bread is highly consumed and loaves among most people, particularly in urban area daily and on holiday.

Although bread is a prominent food for the world population, it is affected the health of the people in case of contaminated with pathogenic microorganisms. Basically, the surface of a fresh baked bread free of viable microorganisms; however, it is subject to contamination by mould spores and bacteria from the air, improperly sanitized utensils, and handlers, transporting equipments and wrapping materials. Ehavald and Estonia [3] explained that more than $90 \%$ of bread contamination occurs during cooling, transporting, slicing and wrapping operation. Moreover, it has been reported that mould spores in proofers' cloths in bakeries can build up enough heat resistance to survive baking [4].

Ogundare and Adetuyi [5] reported from Nigeria, freshly baked bread, after ten minutes had been contained bacterial species, include Bacillus cereus and Staphylococcus spp. and after 48 and $96 \mathrm{~h}$ Staphylococcus cohnii and Bacillus firmus were isolated, respectively. Similarly, after $10 \mathrm{~min}$ mould such as Aspergillus flavus, Aspergillus niger and Penicillium citrinum were reported. Daniyan and Nwokwu [6] reported total aerobic bacterial count ranged from $2.85 \times 10^{4} \mathrm{CFU} / \mathrm{g}$ to $6.21 \times 10^{6} \mathrm{CFU} / \mathrm{g}$, Coli form from $1.19 \times 10^{4} \mathrm{CFU} / \mathrm{g}$ to $2.05 \times 10^{6}$
CFU/g, Staphylococcus from $2.00 \times 104 \mathrm{CFU} / \mathrm{g}$ to $5.52 \times 105 \mathrm{CFU} / \mathrm{g}$ and fungi count ranged from $4.0 \times 10^{3}$ to $1.40 \times 10^{6} \mathrm{CFU} / \mathrm{g}$ and the highest frequency occurrence of Staphylococcus, Escherichia coli and Bacillus spp., respectively were recorded from the beaked bread which are currently emerging to resist various types antibiotics.

Even though, the bread is highly consumed as daily meal in home, cafeteria, and tea shops in Ethiopia [7], the microbial safety of this delicious food is still not documented. On the other hand, the bread is eaten by nearly all of the world population but some groups of the consumers are criticized about the microbial safety of the bread because of unhygienic of transporting material, handlers and storages place of bread [8], which is presently appeared in Jimma town. Hence, having this scenario insight, the present study was designed to assess the microbial load of shop and cafeterias sold bread, and evaluate their antibiotic susceptibility.

\section{Materials and Methods}

\section{Description of the study area}

The study was conducted in Jimma town, Oromia regional state, located at $353 \mathrm{~km}$ southwest of Addis Ababa. The microbial analysis was carried out at Jimma University, Biology department, research

*Corresponding author: Shiferaw Demissie, Department of Biology, Jimma University, P.O. Box 378, Jimma, Ethiopia, Tel: +251-471-112-101; Fax: + 251471-112-214; E-mail: demissieshiferaw5@gmail.com

Received April 30, 2018; Accepted August 10, 2018; Published August 17, 2018

Citation: Demissie S, Natea G (2018) Microbial Quality and Safety of Bread Sold in Cafeteria, Tea and Bread Shop of Jimma Town, Oromia Regional State, Southwest Ethiopia. J Food Ind Microbiol 4: 122. doi:10.4172/2572-4134.1000122

Copyright: @ 2018 Demissie S, et al. This is an open-access article distributed under the terms of the Creative Commons Attribution License, which permits unrestricted use, distribution, and reproduction in any medium, provided the original author and source are credited. 
and Post graduate Laboratory. The geographical location of the town is $7^{\circ} 41^{\prime} \mathrm{N}$ latitude, $36^{\circ} 50^{\prime} \mathrm{E}$ longitude, and an average altitude of $1,780 \mathrm{~m}$ above sea level. The average of minimum and maximum temperature of the town is of 14 and $30^{\circ} \mathrm{C}$, respectively with the annual rainfall ranges from 1138 to $1690 \mathrm{~mm}$ [9].

\section{Sample collection}

A total of 90 samples were collected from baked bread selling shops of Jimma town for past two years. The food samples were purchased from bread sellers at time between 8:00 and $12 \mathrm{am}$. The purchased food samples were added into sterile polyethene bag by bread sellers and transported to Research and Postgraduate Lab. The microbial analysis was conducted within one to three hours of collection. The food samples were kept in the refrigerator at $4^{\circ} \mathrm{C}$ until microbial analysis was conducted.

\section{Sample preparation and microbial enumeration}

Sample preparation: A $25 \mathrm{~g}$ of bread samples were suspended in $225 \mathrm{~mL}$; of buffered peptone water (BPW), and homogenized in Erlenmeyer flasks for $5 \mathrm{~min}$ using shaker at $160 \mathrm{rpm}$. A $1 \mathrm{~mL}$ of homogenized sample was transferred into $9 \mathrm{~mL}$ of BPW, and mixed thoroughly by using vortex mixer. The homogenized food sample was serially diluted from $10^{-1}$ to $10^{-6}$ and $0.1 \mathrm{~mL}$ aliquot of appropriate dilution was plated on pre-solidified plates and incubated at appropriate temperature and period. The colonies was counted from plate containing microbial colonies between 30 and 300 and expressed in colony forming units per gram (CFU/g).

Microbial enumeration: From appropriate serial dilutions, $0.1 \mathrm{~mL}$ of the aliquot was plated on Plate Count Agar (PCA), Violet Red Bile Agar (VRBA) plates [10], MacConkey agar [11], Mannitol Salt Agar (MSA) [12] and incubated at $32^{\circ} \mathrm{C}$ for $48 \mathrm{~h}$ for count Aerobic mesophilic bacteria, Coliform, Enteriobacteriaceae and Staphylococci, respectively, and also for count of Aerobic bacterial spore formers, appropriate serially diluted sample was heat treated in a water bath adjusted at $80^{\circ} \mathrm{C}$ for at least $10 \mathrm{~min}$. Thereafter, $0.1 \mathrm{~mL}$ aliquot was plated on pre-solidified surface of PCA and incubated at $35^{\circ} \mathrm{C}$ for $48 \mathrm{~h}$ [12]. Moreover, after, $0.1 \mathrm{~mL}$ aliquot was plated on pre-solidified surfaces of Potato Dextrose Agar supplemented with $0.1 \mathrm{~g}$ chloramphenicol and incubated at $25^{\circ} \mathrm{C}$ for 5-7 days [11]. Smooth (non-hairy) colonies without extension at periphery were counted as yeasts whereas hairy colonies with extension at periphery were counted as mould.

Microbial analysis: From appropriate aerobic mesophilic countable plate, 10 to 15 colonies with distinct morphological differences were randomly picked from plates and aseptically transferred in to a test tube containing $5 \mathrm{ml}$ of nutrient broth. Then, incubated at $32^{\circ} \mathrm{C}$ for 24 $\mathrm{h}$. The repeatedly sub-culturing isolates were characterized up to genus level based on John [13] bacterial classification manual.

The cell morphology of the bacterial pure isolates was examined microscopically after gram staining, and also the motility of isolates were checked using motility medium. Moreover, after repeatedly purified the agar block of mold culture on PDA, the morphology of hyphal culture was stained using lacto phenol cotton blue and observed under the microscope for identification of fungal genera. The biochemical test including $\mathrm{KOH}$ (potassium hydroxide), Catalase, Oxidation fermentation $(\mathrm{O} / \mathrm{F})$, Cytochrome oxidase tests were conducted, accordingly.

Catalase test: After plate contains young colony had flooded with $1 \mathrm{~mL}$ of $3 \% \mathrm{H}_{2} \mathrm{O}_{2}$ and the formation of gas bubbles was observed. The occurrence of gas bubbles was taken as positive for catalase test [14].
Oxidation fermentation $(\mathbf{O} / \mathrm{F})$ test: Ingredients $(\mathrm{g} / \mathrm{L})$ : Peptone, $2 \mathrm{~g}$; yeast extract, $1 \mathrm{~g} ; \mathrm{NaCl}, 5 \mathrm{~g} ; \mathrm{K}_{2} \mathrm{HPO}_{4}, 0.2 \mathrm{~g}$; glucose, $10 \mathrm{~g}$; bromothymol blue, $0.08 \mathrm{~g}$; agar, $2.5 \mathrm{~g}$; distilled water, $1000 \mathrm{~mL}$; $\mathrm{pH}$, 7.10 were prepared. Accordingly, test tubes containing $15 \mathrm{~mL}$ of freshly prepared medium for $\mathrm{O} / \mathrm{F}$ test were autoclaved and immediately cooled under tap water to avoid dissolution of oxygen in the medium. Then, the broth cultures were inoculated into the medium by stabbing with a sterile straight wire to the bottom. An organism with oxidative metabolism displayed yellow in the upper half of the tube and green in the lower half. An organism with fermentative metabolism displayed yellow in both halves of the tube. Acid formation and growth regions were interpreted after 2 to 5 days of incubation at $32^{\circ} \mathrm{C}$.

Cytochrome oxidase test: Accordingly, freshly prepared reagent $\mathrm{A}$ and $\mathrm{B}$ were mixed in the ratio of $2: 3$ immediately before use. Reagents: A, $1 \%$ a-naphthalene dissolved in absolute ethanol, B, $1 \% \mathrm{~N}$, $\mathrm{N}$-dimethyl-p-phenylenediammonium chloride in distilled water. Three drops of the oxidase reagent were added on to the surface of the growth of isolated colonies of test bacterium. The presence or absence of appearance of a blue color on the colonies was observed within $30 \mathrm{~s}$ Kovacs [15].

Isolation of Salmonella spp.: A $25 \mathrm{~g}$ of food samples was mixed with $225 \mathrm{~mL}$ of BPW and incubate at $37^{\circ} \mathrm{C}$ for $24 \mathrm{~h}$, then $1 \mathrm{~mL}$ preenrichment broth culture was added to $10 \mathrm{~mL}$ of selenite cysteine broth and incubate at $37^{\circ} \mathrm{C}$ for $24 \mathrm{~h}$. Next, a loopful of suspension from secondary enrichment broth was streaked onto Xylose Lysine Deoxycholate Agar (XLD). The presumptive Salmonella colonies was picked off and transfer to $5 \mathrm{~mL}$ nutrient broth and incubate at $37^{\circ} \mathrm{C}$ for $24 \mathrm{~h}$, then streak onto Nutrient Agar for purity and incubate at $37^{\circ} \mathrm{C}$ for $24 \mathrm{~h}$. For conformation the isolates were Salmonella spp., the biochemical testes was done according to the procedure of Johnson and Case [16].

Isolation of Staphylococcus aureus: The golden yellow colony shown on MSA and Gram-positive cocci with clustered arrangement under the microscope were subjected to preliminary biochemical tests coagulase tests. The pure colony of isolates were emulsified with distilled water on the duplicate clean slide (i.e., control and test slide), then, a loopful of human blood plasma was added on the emulsified suspension and mixed. The formation of clumping with in $10 \mathrm{~s}$ was suggested isolates as Coagulase positive [17].

Antimicrobial susceptibility testing for some pathogens: The antimicrobial susceptibility testing for pathogens isolated from bread samples was tested using the disk diffusion method and the microbial cell concentration was adjusted to the standardize turbidity of 0.5 McFarland which is equivalent to $10^{7}-10^{8} \mathrm{CFU} / \mathrm{g}$ [18]. The sterilized cotton swab moistened with bacterial cell suspension had been swabbed on to the Muller-Hinton Agar and allows to drying. Thereafter, the antibiotic discs were dispensed on the medium and incubate at $37^{\circ} \mathrm{C}$ for $18 \mathrm{~h}$ and the zones of inhibition were measured using vernal caliper. The results of the antimicrobial susceptibility were interpreted based on the guidance of National Committee for Clinical Laboratory Standards NCCLS [19]. Finally, the isolates were classified as sensitive, intermediate, or resistant. Intermediates were considered as resistant for purpose of analysis. The following standard drug discs (Oxoid) and their potency $\left(\mu \mathrm{gmL}^{-1}\right)$ were used. As a result chloramphenicol (30), Norflaxacin (10), Amoxicillin (10), Erythromycin (15), Oxacillin (5), Vancomycin (30), penicillin G (10) and Methicillin (5) were used for Staphylococcus aureus. The reference strains were Staphylococcus aureus (ATCC25923). 
Data analysis: The Percentage of Coefficient of variation (\%CV) was calculated to see if there is significant variation in counts within the bread samples analyzed. Mean values of bread samples from different source were compared using one way ANOVA and the significance of differences were considered at 95\% confidence interval $(\mathrm{P}<0.05)$.

\section{Results}

The result of this study indicated highest mean count of Enterobacteriaceae $\left(2.0 \log \mathrm{CFUg}^{-1}\right)$ and S. aureus $\left(3.7 \log _{\mathrm{CFUg}}{ }^{-1}\right)$ were recorded from cafeteria and tea shop, respectively, while considerable number of lactic acid bacteria (LAB $2.8 \log \mathrm{CFUg}^{-1}$ ) was observed in bread shop. On the other hand, the mean counts of Coliform were below detectable level in all bread samples suppliers (Table 1). There was statistically significant difference $(\mathrm{p}<0.05)$ among the mean counts of Aerobic mesophilic bacteria (AMB), Enterobacteriaceae, coliform, Aerobic bacterial spore count (ABS), Staphylococci, LAB, Yeasts and Moulds in all bread samples sources.

\section{Microbial analysis of bread samples}

From the total of 90 bread samples analyzed, 546 bacterial isolates were obtained. The isolates were grouped into six genera based on John's [13] bacterial classification system. Among the identified genera, the predominant bacterial group was Bacillus spp. (40.7\%) followed by Staphylococcus spp. (25.1\%), Micrococcus spp. (10.6\%) and Pseudomonas spp. (9.9\%) (Table 2).

\section{Prevalence of S. aureus and Salmonella spp.}

In the present study, the overall $68.9 \%$ bread samples were positive for $S$. aureus. However, the frequency distribution varied among the bread suppliers. Accordingly, it was as prevalent as $93.3 \%$ of $S$. aureus in tea shop and $70 \%$ in cafeteria bread whereas the lowest prevalence was observed in bread shop (43.3\%) (Figure 1); on the other hand, no Salmonella spp. were detected in any bread samples collected from aforementioned suppliers.

\section{isolates}

Methicillin-resistant patterns of Staphylococcus aureus (MRSA)

The MRSA patterns of S. aureus revealed that, $40.3 \%$ of the isolates were resistant to 4 antibiotics followed by $14.5 \%$ to 4 and 5 antibiotics and fewer isolates (4.8\%) resistant to 7 antibiotics (Table 3 ).

\section{Discussion}

In the present study, the mean total counts of $\mathrm{AMB}\left(5.2 \mathrm{CFUg}^{-1}\right)$ was observed which is in agreement with Daniyan and Nwokwu [6] who reported between 4.5 to $6.8 \log \mathrm{CFUg}^{-1}$ from beaked bread. Unsanitary handlings of bread sellers might cause for cross contamination [20]. Some bread seller is carriers for pathogenic microbes and transfer food borne pathogens to the consumers during bare handling of bread. Salmonella, Campylobacter and E. coli can survive on fingertips for long periods of time. In generally, the mean count of AMB in all bread suppliers shop were 4.7 and above which is belonged to unsatisfactory level [21]. The over loaded of AMB in bread samples could be due to poor hygienic of bakery, bread sellers and transporting materials. Ehavald and Estonia [3] also reported more than $90 \%$ of bread contamination occurs during cooling, transporting, slicing and wrapping processes. AMB loaded food regarded as harmful even if the organisms are not known to be pathogens [22].

The mean count of Enterobacteriaceae in the present study was 1.1 logs $\mathrm{CFUg}^{-1}$ which is very low compare to the earlier report of Mustafa and Abdulla [23] who reported the counts between 2.3 and $4.4 \log \mathrm{CFUg}$ ${ }^{1}$ in traditional foods. Moreover, none of Enterobacteriaceae detected from bread shop. Hence, according to the guideline the Enterobacteriaceae count fit to the acceptable level. The turn down of Enterobacteriaceae count implies that due to low water activities of bread.

In the present study, in any bread suppliers samples the coliform bacteria were below the detectable level in contrast to the report of Daniyan and Nwokwu [6], who reported counts between 4.1 and 6.3 $\mathrm{CFUg}^{-1}$ from beaked bread. The absence of Coliform in the present study could be due to the bread samples less exposed to fecal contamination.

The aerobic bacterial spore (ABS) count $\left(4.6 \log \mathrm{CFUg}^{-1}\right)$ of the present study is higher compared to report by Mosupye and Holy [24] where the counts ranged between 1.2 and $2.0 \log \mathrm{CFUg}^{-1}$ in ready to eat food samples from Johannesburg, South Africa, however, comparable to the finding of Ismail [25], who reported between 2.3 and $4.7 \mathrm{log}$ $\mathrm{CFUg}^{-1}$ from ready to eat food. According to the guideline, in all bread suppliers the mean count of ABS were ranged in unsatisfactory level $\left(>4 \log \mathrm{CFUg}^{-1}\right)$. The higher counts in the present study implies that due to the contamination of bread by the heat resistant spore forming bacteria that survive baking and germinate in the bread after baking, from air during transportation, improperly sanitized utensils, and handlers, transporting equipments and wrapping materials.

\begin{tabular}{|c|c|c|c|c|c|c|c|c|c|c|c|c|c|c|c|}
\hline \multicolumn{16}{|c|}{ Microbial mean counts ( $\log$ CFU $-1 \pm-S D)$} \\
\hline Sample source & No & AMB & $\% \mathrm{CV}$ & Entero & $\% \mathrm{CV}$ & ABS & $\% \mathrm{CV}$ & S. aureus & $\% \mathrm{CV}$ & LAB & $\% \mathrm{CV}$ & Yeast & $\% \mathrm{CV}$ & Mould & $\% \mathrm{CV}$ \\
\hline Tea shop & 30 & $5.9 \pm 0.4$ & 8 & $1.3 \pm 0.2$ & 15 & $4.5 \pm 0.8$ & 17 & $3.7 \pm 0.8$ & 20 & $2.7 \pm 0.7$ & 25 & $3.4 \pm 0.6$ & 17 & $4.6 \pm 0.7$ & 15 \\
\hline Bread shop & 30 & $4.7 \pm 0.4$ & 8.5 & $0.0 \pm 0.0$ & 15 & $4.5 \pm 0.9$ & 17 & $3.7 \pm 0.9$ & 20 & $2.7 \pm 0.8$ & 25 & $3.4 \pm 0.7$ & 17 & $4.6 \pm 0.8$ & 15 \\
\hline Cafeteria & 30 & $4.9 \pm 0.7$ & 14 & $2.0 \pm 0.1$ & 15 & $4.5 \pm 0.10$ & 17 & $3.7 \pm 0.10$ & 20 & $2.7 \pm 0.9$ & 25 & $3.4 \pm 0.8$ & 17 & $4.6 \pm 0.9$ & 15 \\
\hline Total & 90 & $5.2 \pm 0.5$ & & $1.1 \pm 0.1$ & & $4.5 \pm 0.11$ & & $3.7 \pm 0.11$ & & $2.7 \pm 0.10$ & & $3.4 \pm 0.9$ & & $4.6 \pm 0.10$ & \\
\hline
\end{tabular}

AMB: Aerobic Mesophilic Bacteria; Entero: Enterobacteriaceae, ABS: Aerobic Bacterial Spore, S.aureus: Staphylococcus aureus; LAB: Lactic Acid Bacteria; CV: Coefficient of Variance; SD: Standard Deviation; CFU: Colony Forming Unit.

Table 1: Mean of microbial counts $\left(\log \mathrm{CFUg}^{-1}\right)$ from bread sold in Jimma town.

\begin{tabular}{|c|c|c|c|c|c|c|c|}
\hline \multirow[t]{2}{*}{ Bread source } & \multirow[t]{2}{*}{$\begin{array}{c}\text { No of } \\
\text { isolates }\end{array}$} & Bacillus spp. & $\begin{array}{c}\text { Staphylococcus } \\
\text { spp. }\end{array}$ & Micrococcus spp. & Pseudomonas spp. & Acinetobacter spp. & Aeromonas spp. \\
\hline & & Frequency (\%) & Frequency (\%) & Frequency (\%) & Frequency (\%) & Frequency (\%) & Frequency (\%) \\
\hline Tea shop & 209 & $86(41.1)$ & $59(28.2)$ & $21(10)$ & $18(8.6)$ & $14(6.7)$ & $11(5.3)$ \\
\hline Cafeteria & 182 & $70(38.4)$ & $48(27.9)$ & $17(9.3)$ & $25(13.7)$ & $12(6.6)$ & $10(5.5)$ \\
\hline Bread shop & 155 & $66(42.6)$ & $30(19.3)$ & $20(12.9)$ & $11(7.1)$ & $16(10.3)$ & $12(7.7)$ \\
\hline Total & 546 & $222(40.7)$ & $137(25.1)$ & $58(10.6)$ & $54(9.9)$ & $42(7.7)$ & $33(6)$ \\
\hline
\end{tabular}

Table 2: Frequency distribution of dominant bacteria in bread collecting from selling area, Jimma town, southwestern Ethiopia. 


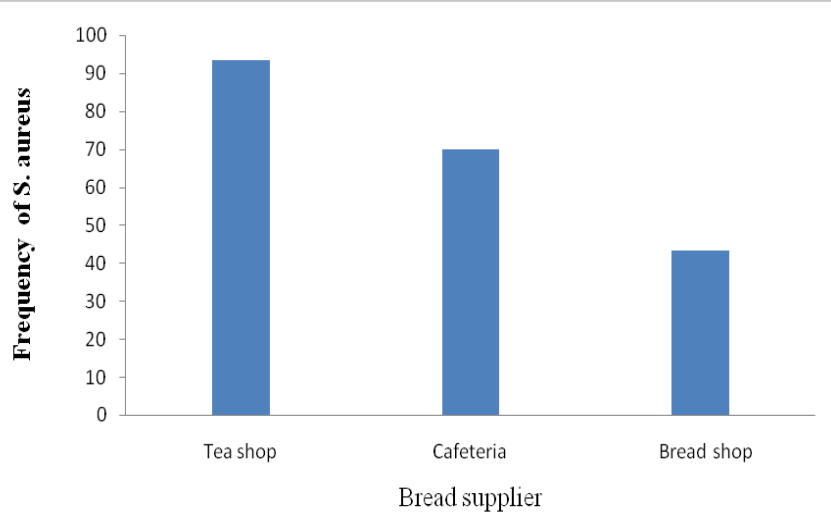

Figure 1: Prevalence of $S$. aureus from bread sample source, Jimma town.

\begin{tabular}{|c|c|c|c|}
\hline $\begin{array}{c}\text { S. aureus } \\
\text { No. of } \\
\text { patterns }\end{array}$ & $\begin{array}{c}\text { Antimicrobial resistance } \\
\text { patterns }\end{array}$ & $\begin{array}{c}\text { No. of isolates } \\
\text { (\%) }\end{array}$ & Total (\%) \\
\hline Two & MET/OX & $6(9.7)$ & $6(9.7)$ \\
\hline Three & MET/OX/NAN & $3(4.8)$ & $6(9.6)$ \\
\hline & MET/OX/AM & $3(4.8)$ & \\
\hline Four & MET/E/OX/AM & $3(4.8)$ & $25(40.3)$ \\
\hline & MET/P/OX/AM & $22(35.5)$ & \\
\hline Five & MET/E/P/OX/AM & $3(4.8)$ & $9(14.5)$ \\
\hline & MET/OX/P/AM/NAN & $6(9.7)$ & \\
\hline Six & MET//E/C/OX/P/AM/ & $6(9.7)$ & $9(14.5)$ \\
\hline & MET//E/OX/P/AM/NAN & $3(4.8)$ & \\
\hline Seven & MET//E/C/OX/P/AM/NAN & $3(4.8)$ & $3(4.8)$ \\
\hline
\end{tabular}

MET: Methicillin; OX: Oxacillin; VAN; Vancomycin; AM: Amoxicillin; P: Penicillin; E: Erythromycin; C: Chloramphenicol.

Table 3: MRSA patterns of $S$. aureus isolated from bread in Jimma town.

The mean counts of $S$. aureus in the present study were 3.3 $\log \mathrm{CFUg}^{-1}$, which is lower than the finding of Daniyan and Nwokwu [6] who reported between 4.3 and $5.7 \log \mathrm{CFUg}^{-1}$ from beaked bread. The higher $S$. aureus in the present study could be due to unhygienic handling of the bread sellers, particularly tea shop and cafeteria workers frequently used bare hand that is why the amount of $S$. aureus was increased in these bread suppliers. Moreover, they did not use special cloth while processing and selling. According to Mensah et al. [26] using of food handling materials is reducing the level of contamination.

In the present study, the mean count of LAB was $2.5 \log \mathrm{CFUg}^{-1}$. This result is lower than the earlier work of Omemu and Omeike [27] that ranging from 4.5 to $9.2 \log \mathrm{CFUg}^{-1}$ in fermented food so called Ogi. Original the dough of bread contain higher amount of LAB, however, the reduction of $\mathrm{LAB}$ in present study could be due to heat treatment of bread during baking and presence of less amount of water activities. Basically the presence of LAB in the food is significance for secure of health to consumers because of it produce antimicrobial compounds that act against pathogenic microorganisms [28].

The mean counts $\left(\log \mathrm{CFUg}^{-1}\right)$ of moulds and yeasts in the present study are 4.0 and 3.0, respectively. This result is in agreement with finding of Daniyan and Nwokwu [6] who reported mean count of molds and yeast between 3.6 to $6.1 \mathrm{log} \mathrm{CFUg}^{-1}$ from bread samples. Normally, the predominant microbial group contaminating the bread during processing and handles are mold and yeast [29]. Yeast spoilage of bread is rare like mould does not survive the baking process USDA [30]. Molds are major concern of bread spoilage and deterioration the quality of bread because of its spore resist harsh environment in nature and easily access to bread from air, bakery and survive baking temperature that is why the number of mold inflated in the present study. According to the report of Daniyan and Nwokwu [6] mould including Absidia corymbifera, Penicillium frequentans westing, Aspergillus flavus, Aspergillus niger and Penicilliumcitrinum were isolated after ten minutes from beaked bread. Besides the visible growth, mold may be responsible for off-flavors and synthesize mycotoxins and allergenic compounds that affect health of consumers [31]. Although it is difficult to prevent moulds from growing on bread, the effort should be made to eliminate such conditions include the hygienity of bakers and sellers should be inspected and certain other protective measures such as general cleanliness in the bakery, proper baking, cooling, wrapping of bread reduces the chances of mold and bacterial growth in baked bread.

The predominant micro floral of bread samples collected from bread suppliers in the present study was generally Bacillus spp. (40.7\%) followed by Staphylococcus spp. (25.1\%), and Micrococcus spp. (10.6\%) in contrast to the report of Daniyan and Nwokwu [6] in which the highest frequency of Staphylococcus, Escherichia coli and Bacillus spp., respectively were recorded from the beaked bread. But in accordance with result of Viwoen and Holy [32], in which of 316 bacterial isolates, $50 \%$ were Bacillus and $31.6 \%$ Micrococcus. The predominance of Bacillus spp. among isolates could be due to its spore contaminate the bread during transportation from air, transporting materials, handlers and from floor of grains and dough, hence, they are equipped with heat-resistant spores [33]. According to Bryan et al. [34], food items that are sold at the stalls have spore-forming bacteria, which are the main concern due to temperature time abuse. Hence, not all spores are eradicated during cooking; rather it could be activated by heat, which initiates them to germinate whenever environmental conditions become suitable for microbial growth. In present study, Coli from and Salmonella were not detected at all in all bread samples similar to the work of Mosupye and Von Holy [24]. This implies that the nature of the bread and heat treatments deny the proliferate of these fastidious microorganisms.

In present study, the antibiotic resistance patterns of the isolates revealed that all of $S$. aureus isolates resistant to three Methicillin group antibiotics including Methicillin, Oxacillin and Penicillin G, and also most of isolates resistance to Amoxicillin (85.5\%) and Erythromycin (40.3\%). This was in agreement with Alexandra et al. [35] who reported that, $100 \%$ of the isolates were resistant to most Methicillin group antibiotics whereas highly resistance than Temilade [36] isolates in which out of 106 isolates of S. aureus, $40.6 \%$ were resistant to erythromycin, $63.2 \%$ to penicillin G, and $20.7 \%$ resistant to oxacillin. This could be, presently isolates $S$. aureus carry mecA gene that encodes a variant Penicillin binding protein (PBP2a or due to the production of penicillinase enzyme that hydrolyzed the beta-lactam ring of penicillin derivatives antibiotics [37]. The alarmingly emerging of MRSA could be due to integration of genetic mobile elements such as plasmids, transposons, and insertion sequence in case of inappropriate or uncontrolled use of antibiotics [38,39]. Therefore, it is necessary to pay more attention to food hygiene practices to reduce or eliminate the risk from resistance to antibiotics and pathogenic bacteria originating from food [40].

\section{Conclusion}

In concluded, the most predominant microbial genera were Bacillus spp., Staphylococci spp. and Micrococcus spp. hence, the presence of these microorganisms could be forecast for the presence of potential pathogens. Although Salmonella spp. and coliform were 
Citation: Demissie S, Natea G (2018) Microbial Quality and Safety of Bread Sold in Cafeteria, Tea and Bread Shop of Jimma Town, Oromia Regional State, Southwest Ethiopia. J Food Ind Microbiol 4: 122. doi:10.4172/2572-4134.1000122

not detected in present study, the presence of high number $S$. aureus cause food intoxication ' that lead to food born diseases. All of $S$. aureus isolates were resistant to three Methicillin group antibiotics including Methicillin, Oxacillin and Penicillin G. Thus, the S. aureus isolates considered as MRSA. The overall microbial quality of bread samples collected from suppliers was poor as compared to the guidelines set by other regulatory bodies. This could be due to poor personal hygienic, transporting materials and exposing to air microorganisms. Thus, the concerned bodies like the municipal and health official of Jimma town should give attention to improve the safety of baked bread by providing training to bakers and bread sellers to keep their personal hygiene, clean the transporting materials and how to manage the hygienty of bread accordingly.

\section{References}

1. Eagle $S$ (2002) Aces high: a passion for great bread is the driving force behind this Toronto bakery. Food in Canada 62: 32-33.

2. Shittu TA, Raji AO, Sanni LO (2007) Bread from composite cassava-wheat flour: I. Effect of baking time and temperature on some physical properties of bread loaf. Food Research International 40: 280-290.

3. Ehavald H, Estonia FB (2009) Food safety risk in management bakeries. Presentation at the $3^{\text {rd }}$ SAFOODNET seminar St Olav's Hotel, Tallinn, Estonia.

4. Ogundana SK, Odia O (1986) Studies on bread spoilage in Nigeria. Nigerian Food Journal, Lagos 2: 203-204.

5. Ogundare AO Adetuyi FC (2003) Studies on the microbial population of bread baked with wheat flour from south western Nigeria. Food, Agriculture and Environment 1: 85-87.

6. Daniyan SY, Nwokwu OE (2011) Enumeration of microorganisms associated with the different stage of bread production in the FUTMIN Bakery, Nigeria. IRJP 2: 88-91.

7. Kuma T (2009) Analysis of Changes in Food Consumption pattern in Urban Ethiopia. Submitted for the Seventh International Conference on the Ethiopian Economy. Ethiopian Development Research Institute, Addis Ababa, Ethiopia.

8. Libby C (2012) White Bread Kills: A history of a national paranoia

9. Alemu A, Tsegaye W, Golassa L, Abebe G (2011) Urban malaria and associated risk factors in Jimma town, south-west Ethiopia. Malar J 10 : 173-200.

10. Weil Q, Hwang S, Chen T (2006) Microbiological Quality of Ready-to-eat Food Products in Southern Taiwan. J Food and Drug Anal. 14: 68-73.

11. Spencer K, John FT, Spencer AL (2007) Food Microbiology Protocols, Humana Press, Totowa, New Jersey, India

12. Acco M, Ferreira FS, Henriques JA and Tondo EC (2003) Identification of multiple strains of Staphyloccocus aureus colonizing nasal mucosa of food handlers. Food Microbiol 20: 489-493.

13. John L. (2012). An introduction to bacterial identification. www.splammo.net,/ bac102/dichotkeyhandout.pdf. (Last accessed on September 23rd 2012).

14. Mac Faddin JF (1980) Biochemical tests for identification of medical bacteria. $\left(2^{\text {nd }}\right.$ edn.), Williams and Wilkins, Baltimore, USA.

15. Kovacs $N$ (1956) Identification of $E$. coli by the oxidase reaction. Natur. (London). 178: 703.

16. Johnson TR, Case C (2007) Laboratory experiments in microbiology. ( $8^{\text {th }}$ edn.), San Francisco: Pearson Education, USA.

17. Cheesbrough M (2006) District laboratory practice in tropical countries Cambridge University Press, New York, USA.

18. Bauer AW, Kirby WM, Sherris JC, Jurck M (1996) Antibiotic susceptibility testing by a standard single disc method. Am J Clin Pathol 451: 493-496.
19. National Committee for Clinical Laboratory standards (2007). Performance standards for antimicrobial susceptibility testing $17^{\text {th }}$ informational supplement.

20. Dawson RJ, Canet C (1991) International activities in street foods. Food Cont 2: 135-139.

21. Gilbert RJ, de Louvois J, Donovan T, Little C, Nye K, et al. (2000) Guidelines for the microbiological quality of some ready-to-eat foods sampled at the point of sale. Commun Dis Public Health 3: 163-167.

22. Sudershan RV, Rao P, Polasa K (2009) Food safety research in India: a review. As J Food Ag-Ind 2: 412-433.

23. Mustafa N, Abdallah MS (2011) Bacteriological quality of street vended UmJingir: A traditional Sudanese food. Afr J Food Agr Nutr 11: 1684-5374.

24. Mosupye FM, Von Holy A (1999) Microbiological quality and safety of ready-toeat Street-vended foods in Johannesburg, South Africa.

25. Ismail SA (2006) Microbiological Quality of Hawawshy Consumed In Ismailia, Egypt. J Food Safety 26: 251-263.

26. Mensah P, Yeboah-Manu D, Owusu-Darko K, Ablordey A (2002) Street foods in Accra, Ghana: how safe are they? World Health Organ 80: 546-554.

27. Omemu AM, Omeike SO (2010) Microbiological hazard and critical control points identification during household preparation of cooked ogi used as weaning food. Int Food Res J 17: 257-266.

28. Shirazinejad AR, Noryati I, Rosma A, Darah I (2010) Inhibitory Effect of Lactic Acid and Nisin on Bacterial Spoilage of Chilled Shrimp. World Acad Sci Eng Technol 65: 163-167.

29. Coda R, Cassone A, Rizzello CG, Nionelli L, Cardinali G, et al. (2011) Antifinga activity of Wickerhamomyces anomalus and Lactobacillus plantarum during sourdough fermentation: identification of novel compounds and long-term effect during storage of wheat bread. In Appl Environ Microbiol 77: 3484-3492.

30. United States Department of Agriculture Food Safety and Inspection Service (USDA, 2012). Food Safety Information (http://ucfoodsafety.ucdavis.edu/ files/26438.pdflast accessed on October 31/2012).

31. Tančinová D, Barboráková Z, Mašková Z, Císarová M, Bojňanská T (2012) The occurrence of Micromycetes in the Bread samples and their Potential ability produce mycotoxins. Journal of Microbiology, Biotechnology and Food Sciences 1: 813-818.

32. Viwoen CR, Holy AV (1997) Microbial populations associated with commercia bread production. J Basic Microbiol 37: 439-444.

33. Hoffman C, Schweitzetr TR, Dalby G (1973) Control of rope in bread. Ind. Engng. Chem. 29: 464-467.

34. Bryan FL, Teufel P, Riaz S, Qadar F, Malike J (1992) Hazards and critica control points of vending operations at a railway station and a bus station in Pakistan. J Food 55: 534-541.

35. Alexandra F, Brita K, Gladys K, Beatriz G, Kataja A, et al. (2011) Methicillin susceptible and resistance $S$. aureus from fam to far impact of food safety. Technoloija mesa. 52: 60-65.

36. Temilade IBO (2009) Effects of Eleutherine American Merr Bulb Extracts on food poisoning $\mathrm{S}$. aureus and its application in food systems. Ph.D thesis, Prince of Songkla University, Thailand.

37. Lowy FD (2003) Antimicrobial resistance: the example of Staphylococcus aureus. J Clin Invest 111: 1265-1273.

38. Deleo FR, Chambers HF (2009) Reemergence of antibiotics-resistant S.aureus in genomics era. J Clin Invest 119: 2464-2474.

39. Szweda P, Schielmann M, Kotlowski R, Gorczyca G, Zelewska M, et al. (2012) Peptidoglycan hydrolases-potential weapons against S.aureus. App Microbiol Biotechnol 96: 1157-1174.

40. Van TTH, Moutafis G, Tran LT, Coloe JP (2007) Antibiotic resistance in foodborne bacterial contaminants in Vietnam and characterization of their antibiotic resistance. Appl Environ Microbiol 73: 6885-6890. 